АЛЕШКИНПетр Федорович - доктор исторических наук, главный редактор общероссийского журнала «Наша молодежь», член Союза писателей России (127486, Россия, г. Москва, Коровинское ш., 6; aleshkin@list.ru)

\title{
ЛОМОНОСОВСКАЯ РЕПРЕЗЕНТАЦИЯ ИСТОРИИ
}

Аннотация. В рецензии на монографию Ю.А. Васильева, М.Ю. Васильевой «Ломоносов - творец и подвижник российского историописания: Репрезентация истории» представлен взгляд на интеллектуальное наследие М.В. Ломоносова в области истории.

Ключевые слова: М.В. Ломоносов, русская историческая школа, история, историческое знание, историософия, историческое познание, история России

Ж анр персональной истории, основанный на представлении исторических личностей в контексте эпохи, в которой они жили, успешно освоен авторами рецензируемой монографии в предыдущих изданиях, получивших позитивную оценку в научной среде [Васильев 2018]. В новой книге о М.В. Ломоносове [Васильев, Васильева 2020] представлено авторское видение интеллектуальных идей великого русского мыслителя в области отечественной истории. Его творческое наследие стоит особняком, не вписываясь ни в какие идеологемы и традиционные форматы.

В этой связи актуально утверждение известного современного политолога А.О. Лапшина о необходимости использования богатейшего наследия отечественных историков для сохранения исторической памяти, что рассматривается как задача не только научная, но и политическая [Лапшин 2020: 9]. Разрушение исторической памяти посредством создания иной реальности искусственными мифологемами представляет угрозу не только для настоящего, но и для будущего [Лапшин 2017a; 2017б].

Исследуя взгляды Ломоносова на историю России, авторы подчеркивают, что одной из основных историософских идей Ломоносова являлось утверждение о древности славянского этноса (в ломоносовской терминологии - народа) и, соответственно, о древнем происхождении российского народа. Его «Древняя российская история от начала российского народа до кончины великого князя Ярослава Первого, или до 1054 года» состоит из двух частей. Часть I, озаглавленная «О России прежде Рурика», посвящена проблеме происхождения российского народа. В ней затрагиваются вопросы автохтонности древних жителей, происхождении славян, уходящем в глубину веков, их нравов, поведения и верований, миграционных, демографических и этнических процессов, происходивших в далеком прошлом на территории России.

Авторы соглашаются с этой идеей русского ученого и критикуют принятое официально мнение, что история Российского государства начинается в 862 г. Они заявляют, что официально объявленное в России в 2012 г. начало зарождения российской государственности, связанное с призванием Рюрика, никак не может соответствовать ломоносовской исторической схеме. Начало Руси, по Ломоносову, «не должно производить и начинать от времени пришествия Рурикова к новгородцам, ибо оно широко по восточно-южным берегам Варяжского моря простиралось от лет давных» [Ломоносов 1986: 75].

В книге отмечается, что признание начала русской истории задолго до Рюрика у Ломоносова основано на самой структуре его «Древней российской истории», в которой лишь вторая часть, повествовательная по содержанию, откры- 
вается началом княжения Рюрика. Ломоносов отделил вопрос о зарождении государственности от начала династии Рюриковичей - до призвания Рюрика в пределах русских территорий уже происходил процесс формирования основ государственности. Данное заключение представляется убедительным, иначе невозможно объяснить, например, летописные свидетельства о совместном решении разноэтническими племенами (славянами-кривичами, ильменскими словенами, финно-угорскими - чудью и весью) важных вопросов регулирования и управления на своих землях: о форме и условиях правления, обсуждении, выборе достойной кандидатуры князя и его призвания, а также сведения о предшествовавших временах, когда указанные племена платили дань варягам, затем отказались от нее, периоде междоусобиц. В данном контексте призвание Рюрика воспринимается как следствие уже сложившихся ранних форм государственности и общественной организации в русской истории.

Хронологически для Ломоносова было неоспоримо происхождение многочисленных славянских народов в российских пределах прежде Рождества Христова, а историческая роль славян на этих землях проявилась уже в первые века нашей эры. Ломоносов отстаивал не хронологическую определенность российской государственности, а древность, самобытность славян и русской культуры. История России для него - это прежде всего история российского народа, начавшаяся задолго до возникновения государственности.

Авторы приходят к выводу, что как историк Ломоносов был ярким патриотом своего отечества, утверждавшим величие и славу своей родины. Это был патриотизм национальный, народный. В ломоносовском патриотизме проявились качества поморского характера и духа как неповторимый тип русского человека, в становлении мировоззрения которого природные основания лес и вода - явились определяющими началами родного мироздания, дополненными отсутствием ментальных архетипов крепостного права и монголотатарского ига. Таково авторское восприятие образа Ломоносова, основанное на личном отношении к истокам идентичности собственного архангелогородского рода.

Современное понимание истории позволяет позиционировать М.В. Ломоносова как выдающегося историка, резюмируют авторы свою оценку вклада великого ученого в изучение русской истории. По их мнению, комплекс идей, предложенных Ломоносовым, актуален и сегодня: он создал основу для последующего научного осмысления древнерусского периода истории России. В числе значимых идей Ломоносова - рассмотрение российской истории в контексте истории славян и в мировом историческом процессе. В данном направлении Ломоносов сформулировал целостное для своего времени представление о происхождении славян, русского народа, древнерусского государства. Русская история рассматривалась как важная часть мирового исторического процесса, определялась роль русского народа в мировой истории. В соответствии с просветительской традицией Ломоносов рассматривал отечественную историю в контексте культуры, принадлежности к цивилизации, альтернативной варварству. Научно обоснованы его идеи о древности славянских народов в Европе и о значительной роли славян в общеевропейской и мировой истории, об участии славян в Великом переселении народов, об их исторической роли в падении и разрушении Римской империи, хронологически определяющем переход Европы от Античности к Средневековью. Историческая наука подтверждает идеи о скифах и сарматах как древних этносах на территории России, о складывании древнерусской народности на полиэтнической основе, о смешанной этнической природе населения России, образованной в процессе исторической эволюции, о древности русского народа и наличии у него само- 
стоятельной культуры, о сложном составе русского народа, образовавшегося за счет смешения славянских и финно-угорских племен. Исторический опыт Ломоносова предвосхитил принцип историзма XIX в.: истоки идентичности нации, народа, социального института находятся в их прошлом [Васильев 2009a; 2009б].

По оценке авторов, наследие М.В. Ломоносова в российском историописании можно по достоинству оценить лишь с учетом историософской парадигмы. В исторических построениях Ломоносова закладывались основы историософской традиции России. Именно в таком ключе следует расценивать идеи мыслителя - как передовые для исторического знания России середины и второй половины XVIII в. Наследие Ломоносова стало интеллектуальной основой для последующего становления исторической науки в России.

Авторы обосновывают утверждение о влиянии идей профессора Марбургского университета Христиана Вольфа на мировоззрение Михаила Ломоносова [Васильев, Васильева 2014]. По оценке автора, фундаментальные черты мышления Ломоносова сложились под непосредственным влиянием Вольфа, в частности, он воспринял вольфианский телеологический подход в области познания, который нашел применение в разработке истории. По авторской оценке, в исторических концептах Ломоносова превалирует телеологизм вольфовского направления. В данном случае опровергается мнение русского марксиста Георгия Плеханова о незначительности влияния Вольфа на мировоззрение Ломоносова. Благодаря своему немецкому учителю Ломоносов сформировался как теоретик и ученый, стремившийся не ограничивать свою деятельность эмпирической наукой. Тем не менее Ломоносов не идентифицируется как вольфианец.

Представляется, что в контексте русской исторической школы концепты М.В. Ломоносова нашли развитие в теоретических разработках выдающегося российского теоретика истории Н.И. Кареева и других представителей русской исторической школы [Васильев 2012; 2014]. Помимо этого, важно отметить рецепцию многих идей Ломоносова в наследии ведущих школ немецких историков. В этой связи примечательна созвучная оценка А.Л. Шлецером и М.В. Ломоносовым важных явлений русской истории (роль славян в мировой истории, образ исторического процесса в виде великой реки, понимание истории как многоуровневой и многофакторной системы и др. [Шлецер 1809]).

В исследовании рассматривается просветительская деятельность М.В. Ломоносова, предложившего способ познания российской истории при помощи средств изобразительного и мозаичного искусства. Изучение российской истории при помощи средств изобразительного искусства, в первую очередь живописных картин, соответствовало духу европейского Просвещения. По оценке авторов, оригинальные разработки в познании возвышенного в истории России созвучны современным подходам в европейском историописании. Так, историософские разработки Ломоносова созвучны с современной теорией возвышенного исторического опыта Франклина Анкерсмита, предложившего обратиться к непосредственному восприятию прошлого в аристотелевской парадигме.

\section{Список литературы}

Васильев Ю.А. 2009а. О методологических основаниях русской исторической школы: историософские аспекты. Ч. І. - Знание. Понимание. Умение. № 1. C. 49-58.

Васильев Ю.А. 2009б. О методологических основаниях русской историче- 
ской школы: историософские аспекты. Ч. ІІ. - Знание. Понимание. Умение. № 2. С. 78-88.

Васильев Ю.А. 2012. Взгляд на эпометаморфоз сквозь призму всемирно-исторической точки зрения. - Век глобализации. № 1. С. 4657.

Васильев Ю.А. 2014. Идеи М.В. Ломоносова в русской исторической школе. - Знание. Понимание. Умение. № 2. С. 141-148.

Васильев Ю.А. 2018. Юрий Андропов. На пути к власти. М.: Вече. 416 с.

Васильев Ю.А., Васильева М.Ю. 2014. Влияние идей Христиана Вольфа на мировоззрение М. В. Ломоносова. - Власть. № 3. С. 121-125.

Васильев Ю.А., Васильева М.Ю. 2020. Ломоносов - твореи и подвижник российского историописания: Репрезентация истории. М.: ЛЕНАНД. 176 с.

Лапшин А. О. 2017а. О слове и цифре. - Власть. Т. 25. № 8. С. 7-9.

Лапшин А.О. 2017б. Еще раз о власти. - Власть. Т. 25. № 12. С. 180-185.

Лапшин А.О. 2020. К осмыслению истории вчера и сегодня. - Bласть. Т. 28. № 2. C. 9-15.

Ломоносов М.В. 1986. Древняя российская история от начала российского народа до кончины великого князя Ярослава первого, или до 1054 года. Избранные сочинения: в 2 т. Т. 2. История. Филология. Поэзия. М.: Наука. 496 с. 227 c.

Шлецер А.Л. 1809. Представление всеобщей истории. СПб: Святейший Синод.

Aleshkin Petr Fedorovich, Dr.Sci. (Hist.), Editor-in-Chief of «Our Youth» journal, Member the Union of Writers of Russia (6 Korovinskoye Highway, Moscow, Russia, 127486; aleshkin@list.ru)

\section{LOMONOSOV REPRESENTATION OF HISTORY}

Abstract. The review of the monograph by Yu.A. Vasil'ev and M.Yu. Vasil'eva "Lomonosov - Creator and Architect of Historical Writing in Russia: Representation of History" presents the view on the intellectual heritage of M.V. Lomonosov in the field of history

Keywords: M.V. Lomonosov, Russian historical school, history, historical knowledge, historiosophy, historical cognition, Bussian history 